\title{
In Memory of James Cook
}

E leven years ago, I met James Cook, the Young Adult Specialist at the Dayton-Montgomery County Library in Ohio since 1976, at the ALA conference in New York City. We sat next to each other at the Scholastic luncheon where the Dear America series was being unveiled. A few months later, we reconnected at the ALAN Workshop, and from that point on became fast friends.

James had a gentle and wry sense of humor, and he was a devout Christian. He served as a deacon at his Methodist church and frequently preached. As a matter of fact, we often went to interesting new churches together on Sunday mornings in the various cities where professional conferences were held, and enjoyed our spiritually oriented conversations.

He had the most amazing singing voice-deep and rich and clear. Hymns took on a new radiance when he sang them. But he didn't stop there-he was also a great fan of Motown music, and thought Diana Ross was the best! He could be stopped in his tracks mid-conversation with the happiest smile on his face if he heard one of her songs playing.

James loved teens and he loved reading. He enjoyed booktalking and was expert at it. Twice I had the pleasure of doing a booktalking breakout session with him at ALAN Workshops. He was a popular speaker not only at ALAN Workshops, but also throughout Ohio. He served on the Newbery Award and Margaret Edwards Award committees for ALA, chaired the YALSA Intellectual Freedom Committee, and served on the Virginia Hamilton Conference Advisory Board. He was currently serving on ALA's Michael L. Printz Award Committee and the ALAN Board of Directors, and had recently completed his first semester teaching "Library Materials \& Services for Young Adults” at Kent State University, where he also served on the School of Library and Information Science Advisory Board.

His sudden death on August 1, 2005 was a shock to his wide group of friends and colleagues throughout the Young Adult library and literature world. When his mother passed away last spring, James was so surprised at receiving over 100 cards from sympathizers. "I didn't know that many people knew and cared about me," he chuckled. I don't think James ever realized what a truly important and respected person he was in our profession, and what great contributions he made. He will be missed terribly, as an icon in our field and as a true gentleman.

Diane Tuccillo, ALAN President-Elect

\section{For Immediate Release, August 11, 2005}

Kent State University School of Library and Information Science Announces Establishment of the James E. Cook Scholarship Fund

A memorial scholarship/award fund in honor of James E. Cook has been established by Kent State University. As we move forward, we will work closely with friends and colleagues in Dayton and around the state to establish final criteria for this award or scholarship. The graduate student recipient will be selected on the basis of continuing James' good, important work of connecting teens and libraries. The resulting criteria for the award will also require that the recipient has a love for YA literature and a passion for telling others about what he or she has read. This will be a very special scholarship/award just as James was a very special individual.

Contributions to this fund may be made online by visiting https://www.givetokent.org/secure/form1.asp and indicating in step 3, fill in the white box that your contribution is "in memory of James E. Cook." Contributions may also be sent by mail to: KSU Development Office, P.O Box 5190, 1061 Fraternity Circle, Kent OH 44242.

Please remember to indicate on the memo portion of your check that your contribution is "In memory of James E. Cook." 